\title{
PERBEDAAN TINGKAT STRES KERJA ANTARA PERAWAT INSTALASI GAWAT DARURAT (IGD) DENGAN PERAWAT INSTALASI RAWAT INAP DI RUMAH SAKIT UMUM DR.PIRNGADI MEDAN
}

\author{
Lia Puspita Sari ${ }^{1}$, Mutiara Nauli ${ }^{2}$ \\ ${ }^{1}$ Mahasiswa STIKes Nurliana, Medan, Indonesia \\ ${ }^{2}$ Dosen STIKes Nurliana, Medan, Indonesia \\ Email: $\underline{{ }^{1} \text { Liapuspita309@gmail.com, }} \underline{{ }^{2} \text { mutiara.nsrg@gmail.com }}$
}

\begin{abstract}
Abstrak
Stres kerja dipandang sebagai salah satu masalah psikososial di tempat kerja. Hingga saat ini, stres kerja masih menjadi masalah utama dan aktual. Setiap individu dan organisasi memiliki respon yang berbeda terhadap stimulasi stres. Stres kerja yang tinggi dapat menurunkan kreativitas dan kinerja, tidak mampu mengambil keputusan, emosi tidak stabil, kualitas pelayanan dan kesehatan menurun. Tujuan penelitian ini adalah untuk mengetahui perbedaan tingkat stres kerja pada perawat IGD dan perawat rawat inap di RSUD Dr. Pirngadi Medan tahun 2019. Jenis penelitian ini adalah deskriptif analitik dengan desain populasi Cross Sectional dalam penelitian ini adalah perawat gawat darurat dan perawat rawat inap, pengambilan sampel adalah teknik total sampling dengan jumlah 60 orang, data diambil melalui kuesioner dan data diolah secara univariat dan bivriate, menggunakan T-Test. Hasil penelitian mayoritas tingkat stres kerja perawat perawat gawat darurat ringan sebanyak 20 orang $(66,7 \%)$. Tingkat stres perawat rawat inap berada pada kategori sedang yaitu 20 orang $(66,7 \%)$, nilai $T$ Test $p=0,005(\mathrm{p} \leq 0,005)$. Diharapkan pihak manajemen memperhatikan beban kerja yang mempunyai beban pada perawat yang dapat mempengaruhi kesehatan perawat dan pelayanan kepada pasien kurang optimal sehingga kualitas kepuasan pasien tidak dapat tercapai.
\end{abstract}

Kata kunci : Perbedaan, Stres kerja, Perawat

\begin{abstract}
Job stress is seen as one of the psychosocial problems in the workplace. Until now, work stress is still a major and actual problem. Each individual and organization has a different response to stress stimulation. High work stress can reduce creativity and performance, unable to make decisions, unstable emotions, decreased quality of service and health. The purpose of this study was to determine differences in work stress levels in emergency room nurses and inpatient nurses at Dr. Hospital. Pirngadi Medan in 2019. This type of research is descriptive analytic with Cross Sectional population design in this study are emergency nurses and inpatient nurses, sampling is a total sampling technique with a total of 60 people, data taken through questionnaires and data processed by univariate and bivriate, using T-Test. The results of the study the majority of the work stress levels of light emergency nurse nurses were 20 people (66.7\%). The stress level of inpatient nurses is in the moderate category of 20 people (66.7\%), the value of the TTest is $p=$
\end{abstract}


$0.005(p \leq 0.005)$. It is expected that the management pays attention to the workload that has a bearing on nurses that can affect the health of nurses and services to patients are less than optimal so that the quality of patient satisfaction cannot be achieved

\section{Keywords: Differences, Stress Levels of Work, Nurses}

\section{Pendahuluan}

Prevalensi stres kerja pada tenaga kesehatan khususnya perawat bervariasi pada setiap negara di dunia. Di Negara Amerika pada tahun 2014 stres kerja pada perawat mencapai 89,2\% diikuti oleh beberapa negara lain seperti Korea selatan 85,2\% pada tahun 2017, Eropa 58,2\% pada tahun 2011, India 50\% pada tahun 2018 dan Australia 44,82\% pada tahun 2016. Jadi, pada negara yang lebih maju stres kerja perawat lebih tinggi. Hal yang sama di tunjukkan oleh negara berkembang salah satunya Indonesia (Khamisa, 2016).Indonesia merupakan negara berkembang dengan banyak pulau yang memiliki latar belakang stres kerja yang berbeda. Di Semarang prevalensi stres kerja pada perawat pada tahun 2013 mencapai angka 82,8\%, diikuti oleh Manado dengan angka 54,3\% pada tahun 2016, Kalimantan 60,9\% pada tahun 2017, Banda Aceh 52,5\% pada tahun 2017, Gorontalo 55,1\% padatahun 2015, Yogyakarta 80,3\% pada tahun 2015 dan Padang 55,8\% pada tahun 2017 (Afra \& Dari beberapa data di atas dapat di simpulkan bahwa stres kerja di setiap kota di Indonesia memiliki nilai yang cukup tinggi. Stres kerja yang tinggi jika di biarkan akan berdampak negatif pada individu dan organisasi (Afra, 2017).

Adapun beberapa faktor yang mempengaruhi stres kerja pada tenaga kesehatan khusunya perawat bermacam- macam. Faktor stres kerja terdiri dari beban kerja, kasus kematian dan sekarat, emosional yang tidak adekuat, ketidaksiapan menangani pengobatan, konflik dengan dokter, konflik dengan rekan kerja, masalah dengan supervisor, dan masalah dengan pasien dan keluarga Dari beberapa faktor tersebut terdapat faktor yang dominan dalam mempengaruhi stres kerja pada perawat ialah beban kerja.

Rumah Sakit Umum Dr Pirngadi Medan merupakan rumah sakit rujukan untuk wilayah Sumatera Utara yang memiliki beberapa unit ruang rawat inap salah satunya ialah ruang rawat inap dan Instalasi Gawat Darurat. Penelitian yang dilakukan oleh Rihulai (2012) mengatakan bahwa perawat unit rawat inap penyakit dalam memiliki tingkat stres yang lebih besar dibandingkan dengan perawat unit lain sebesar $66,72 \%$ hal ini kerena perawat ruang rawat inap lebih banyak memberikan pelayanan untuk kebutuhan pasien yang berbagai macam dan banyak permintaan keluarga pasien, hal ini yang membedakan tingkat stress perawat ruang rawat inap dengan perawat IGD berbeda baik dari segi beban kerja maupun tuntutan keluarga dan pasien.

Berdasarkan studi awal yang telah dilakukan pada 10 perawat Di Instalasi Rawat Inap Penyakit Dalam Rumah Sakit Umum Dr Pirngadi Medan pada tanggal 1 Juni 2019 di dapatkan hasil kuesioner bahwa 6 perawat yang bekerja di ruangan IGD tersebut mengeluhkan stres kerja berat, dan 4 perawat mengalami stres kerja ringan. Sedangkan pada beban kerja di ruang rawat inap 7 perawat mengeluhkan beban kerja yang berat dan 3 perawat mengeluhkan beban kerja ringan. Saat di wawancarai dari 10 perawat 5 perawat mengeluhkan sering pusing, kelelahan, emosi yang tidak terkontrol, sulit berkonsentrasi dalam bekerja, merasakan kebosanan dan beban kerja yang begitu berat karena tuntutan pasien dan keluarga dengan diagnosa yang bermacammacam.

\section{Metode Penelitian}

Jenis penelitian ini adalah deskriptif Analitik dengan desain Cross Sectional. Lokasi penelitian ini dilaksanakan di ruang Instalasi gawat darurat (IGD) dan instalasi ruang rawat inap kelas III Rumah Sakit Umum Dr. Pirngadi Medan. Populasi adalah keseluruhan subjek 
penelitian, populasi dalam penelitian ini adalah seluruh perawat yang bertugas di Instalasi Gawat darurat berjumlah 30 orang dan perawat yang pertugas di instalasi rawat inap berjumlah 30 orang Rumah Sakit Umum Dr. Pirngadi Medan yang berjumlah 60 orang. Sampel merupakan bagian dari populasi yang akan diteliti secara langsung. Analisis data dengan analisa univariat dan analisa bivariat. 


\section{Hasil dan Pembahasan}

\section{Analisa Univariat}

Tabel 4.1. Distribusi Frekuensi Data Demografi Perawat IGD Dan Perawat Ruang Rawat Inap Rumah Sakit Umum Dr. Pirngadi Medan Tahun 2019

\begin{tabular}{|c|c|c|c|c|c|c|}
\hline No & $\begin{array}{l}\text { Perawat } \\
\text { IGD }\end{array}$ & $\begin{array}{c}\text { Frekuensi } \\
\text { (F) }\end{array}$ & $\begin{array}{c}\text { Persentase } \\
(\%)\end{array}$ & $\begin{array}{c}\text { Perawat } \\
\text { Rawat Inap }\end{array}$ & $\begin{array}{l}\text { Frekuensi } \\
\text { (F) }\end{array}$ & $\begin{array}{c}\text { Persentase } \\
(\%)\end{array}$ \\
\hline \multirow[t]{6}{*}{1} & Usia & & & Usia & & \\
\hline & 20-30 tahun & 4 & 13,3 & 20-30 tahun & 12 & 40,0 \\
\hline & $31-40$ tahun & 11 & 36,7 & $31-40$ tahun & 9 & 30,0 \\
\hline & 41-50 tahun & 13 & 43,3 & $41-50$ tahun & 6 & 20,0 \\
\hline & $\geq 51$ tahun & 2 & 6,7 & $\geq 51$ tahun & 3 & 10,0 \\
\hline & Total & 30 & 100 & Total & 30 & 100 \\
\hline \multirow[t]{5}{*}{2} & Jenis & & & Jenis & & \\
\hline & Kelamin & 19 & 63,3 & Kelamin & & \\
\hline & Laki-laki & 11 & 36,7 & Laki-laki & 12 & 40,0 \\
\hline & Perempuan & & & Perempuan & 18 & 60,0 \\
\hline & Total & 30 & 100 & Total & 30 & 100 \\
\hline \multirow[t]{4}{*}{3} & Pendidikan & & & Pendidikan & & \\
\hline & D III & 10 & 33,3 & D III & 13 & 43,0 \\
\hline & $\mathrm{S} 1$ & 20 & 66,7 & S 1 & 17 & 57,0 \\
\hline & Total & 30 & 100 & Total & 30 & 100 \\
\hline
\end{tabular}

Berdasarkan tabel 4.1 diatas mayoritas responden dengan kategori usia 41-50 tahun berjumlah 13 orang $(43,3 \%)$, jumlah jenis kelamin laki-laki berjumlah 19 orang $(63,3 \%)$, berpendidikan S1 dengan jumlah 20 orang $(66,7 \%)$, dan pekerjaan sebagai perawat ahli pertama berjumlah 20 orang $(66,7 \%)$. Sedangkan perawat ruang rawat inap mayoritas usia dengan kategori 20-30 tahun berjumlah 12 orang $(40,0 \%)$, jumlah jenis kelamin perempuan berjumlah 18 orang $(56,3 \%)$, berpendidikan DIII dengan jumlah 17 orang $(57,0 \%)$, dan pekerjaan sebagai perawat terampil berjumlah 17 orang $(66,7 \%)$.

Tabel.4.2 Distribusi Frekuensi Tingkat Stres Perawat IGD dan Rawat Inap Rumah Sakit Umum Dr. Pirngadi Medan Tahun 2019

\begin{tabular}{lccccc}
\hline $\begin{array}{l}\text { Tingkat Stres } \\
\text { Perawat IGD }\end{array}$ & $\begin{array}{c}\text { Frekuensi } \\
\text { (F) }\end{array}$ & $\begin{array}{c}\text { Persentase } \\
\mathbf{( \% )}\end{array}$ & $\begin{array}{c}\text { Tingkat } \\
\text { Stres } \\
\text { Perawat } \\
\text { Rawat Inap }\end{array}$ & $\begin{array}{c}\text { Frekuensi } \\
\text { (F) }\end{array}$ & $\begin{array}{c}\text { Persentase } \\
(\mathbf{\%})\end{array}$ \\
\hline Ringan & 20 & 66,7 & Ringan & 5 & 16,7 \\
Sedang & 6 & 20,0 & Sedang & 20 & 66,7 \\
Berat & 4 & 13,3 & Berat & 5 & 16,7 \\
\hline \multicolumn{1}{c}{ Total } & 30 & 100 & Total & 30 & 100 \\
\hline
\end{tabular}

Berdasarkan Tabel 4.2 mayoritas tingkat stres responden adalah ringan dengan jumlah 20 orang $(66,7 \%)$, sedangkan perawat ruang rawat inap mayoritas tingkat stres responden sedang dengan jumlah 20 orang $(66,7 \%)$. 
Tabel 4.3 Perbedaan Tingkat Stres Kerja Antara Perawat IGD dengan Perawat Instalasi Rawat Inap Di Rumah Sakit Umum Dr. Pirngadi Medan Tahun 2019

\begin{tabular}{|c|c|c|c|c|c|c|c|}
\hline & $\mathbf{N}$ & Mean & $\begin{array}{r}\mathrm{Pa} \\
\text { Diff }\end{array}$ & $\begin{array}{l}\text { red } \\
\text { rence }\end{array}$ & $\mathbf{T}$ & Df & $\begin{array}{c}\text { Sig } \\
\text { (2tailed) }\end{array}$ \\
\hline & & & Lower & Upper & & & \\
\hline $\begin{array}{l}\text { Tingkat stres keria } \\
\text { perawat IGD }\end{array}$ & 30 & 1.4667 & & & & & \\
\hline $\begin{array}{l}\text { Tingkat stres kerja } \\
\text { perawat rawat inap }\end{array}$ & 30 & 2.0000 & -89673 & -16993 & $-3,002$ & 29 & 0,005 \\
\hline
\end{tabular}

Berdasarkan tabel 4.3 hasil penelitian di dapatkan perbedaan tingkat stress antara perawat IGD dengan Perawat ruang rawat inap, setelah dilakukan uji Paried sampel tes di dapatkan sig $\mathrm{P} 0,005=(\mathrm{p} \leq 0,05)$.

Banyak hal yang dapat menjadi faktor penyebab stres kerja pada perawat. Beberapa penelitian menunjukkan hasil bahwa faktor yang berhubungan dengan kerjadian stres kerja pada perawat terdiri dari shift kerja malam, konflik peran ganda, kurangnya dukungan sosial, konflik antara pekerjaan dengan keluarga, tuntutan tugas yang beragam dan tidak sesuai dengan kompetensi, beban kerja berlebih, kondisi kerja tidak nyaman, ketidakpastian pekerjaan, tidak adanya penghargaan, promosi yang berlebih atau promosi yang kurang, dan tidak seimbangnya jumlah rasio tenaga perawat dengan jumlah pasien (Firman, 2015).

Faktor yang lain yang dapat mempengaruhi stres kerja yaitu Umur adalah lama hidup individu yang terhitung mulai saat dilahirkan sampai berulang tahun terakhir. Umur merupakan risiko yang dapat meningkatkan stres kerja secara signifikan (Rasasi, 2015). Individu dengan umur yang lebih tua mengalami stres yang lebih rendah karena pengalamannya dalam menghadapi stres sudah lebih baik dibandingkan dengan individu berumur muda. Hasil uji statistik menunjukkan bahwa perawat dengan umur $\leq 36$ tahun memiliki risiko stres sebesar 93,9\% (Dewi, 2015).

Hasil penelitian pada perawat di RSU Dr. Pirngadi Medan di IGD mayoritas jenis kelamin laki-laki 19 orang $(63,3 \%)$ dengan tingkat stres ringan, sedangkan jenis kelamin di ruang rawat inap mayoritas adalah perempuan 18 orang $(60 \%)$ dan tingkat stres sedang penelitian ini menunjukkan bahwa jenis kelamin perempuan memilki risiko stres sebesar. Adanya hubungan antara jenis kelamin dan stres kerja ditunjukkan oleh penelitian yang dilakukan oleh Sahraian dengan nilai probabilitas sebesar 0,004 Sahraian (2013).

Stres kerja yang dialami para perawat dapat menimbulkan dampak yang berbeda pada setiap orang. Perubahan yang timbul akibat stres dapat berupa perubahan perilaku dan mempengaruhi kesehatan mental dan fisik (Gibson, 1997). Stres yang berkepanjangan dapat menyebabkan masalah psikologis yang mengarah ke psikiatri penyalahgunaan obat, minum alkohol dan kemudian tidak datang untuk bekerja serta dapat menurunkan daya tahan tubuh sehingga mudah terserang infeksi (Depkes RI, 2006).

\section{Kesimpulan}

Tingkat stres kerja perawat di rungan Instalasi Gawat Darurat (IGD) Rumah Sakit Umum Dr. Pirngadi Medan Tahun 2019 mayoritas perawat memiliki stres ringan berjumlah 20 orang $(66,7 \%)$. Tingkat stres kerja perawat di rungan rawat inap Rumah Sakit Umum Dr. Pirngadi Medan Tahun 2019) mayoritas perawat memiliki stres sedang berjumlah 20 orang $(66,7 \%)$. Terdapat perbedaan tingkat stres antara perawat Instalasi Gawat Darurat (IGD) dengan perawat di 
rungan rawat inap Rumah Sakit Umum Dr. Pirngadi Medan Tahun 2019, yang didasari beberapa faktor yang dapat mempengaruhi tingkat stres salah satunya beban kerja, ketidak seimbangan antara perawat dengan jumlah pasien dan banyaknya tuntutan pasien maupun keluarga pasien, setelah dilakukan uji didapkan hasil denganhasil uji $T$ tes $=0,005(\leq 0,05)$.

\section{Referensi}

Afra, 2017. Tingkat Stres Kerja dalam Organisasi Diakses pada tanggal 14 Juli 2017 http://jurnal-sdm. blogspot. co.id /2017 /02 / stres-kerja-definisi- stress kerja dalam organisasi kategori dan. Html.

Departemen Kesehatan. 2006. Promosi Kesehatan di Tempat Kerja. Jakarta: Dirjen Bina Kesehatan Masyarakat.

Dewi. 2015. Stres Kerja : Definisi, Kategori dan Faktor Penyebab Stres Kerja. Diakses pada tanggal 2 September 201514.51 http: //jurnal-sdm.blogspot. co. id/ 2011/ 02/ stres-kerjadefinisi-kategori dan.Html.

Firman. 2015. Hubungan Shif Kerja Dengan Stress Kerja Pada Karyawan Bagian Operation PT Newmont Nusa Tenggara Di Kab. Sumbawa Barat. Jurnal. KESMAS 5:1-67, Diakses Tanggal 4 Desember 2015.

Khamisa. 2016. Work Related Stress, Burnout, Job Satisfaction, And General Health of Nurses. Int. J. Environ. Res. Public Health 2016.

Sahrian. 2013. Hubungan anatara jenis kelamin dengan stress kerja pada perawat di rumah sakit umum Dr. Pirngadi Medan. Jurnal Ilmiah Kesehatan, Vol. Maret 2013 